\title{
Clinical, manometric and profilometric evaluation after surgery for Hirschsprung's disease. Comparison between the modified Duhamel and the transanal rectosigmoidectomy techniques ${ }^{1}$
}

\author{
Avaliação clínica, manométrica e profilométrica após correção cirúrgica para doença de \\ Hirschsprung. Comparação entre as técnicas de Duhamel modificado e a retossigmoidectomia \\ transanal modificada
}

\author{
Elaine Cristina Soares Martins ${ }^{\mathrm{I}}$, Fábio Luis Peterlini ${ }^{\mathrm{II}}$, Djalma José Fagundes ${ }^{\mathrm{III}}$, José Luiz Martins ${ }^{\mathrm{IV}}$ \\ ${ }^{\mathrm{I}} \mathrm{PhD}$, Division of Pediatric Surgery, Department of Surgery, UNIFESP, Sao Paulo, Brazil. \\ ${ }^{\text {II }} \mathrm{PhD}$, Division of Pediatric Surgery, Department of Surgery, UNIFESP, Sao Paulo, Brazil. \\ III PhD, Associate Professor, Division of Surgery and Experimentation, UNIFESP, Sao Paulo, Brazil. \\ ${ }^{\text {Iv }}$ PhD, Full Professor, Division of Pediatric Surgery, Department of Surgery, UNIFESP, Sao Paulo, Brazil.
}

\begin{abstract}
Purpose: To evaluate fecal continence, anorectal manometry (AM) and profilometry (P), in patients operated for congenital megacolon, using either the modified Duhamel technique (MDT) or the modified transanal rectosigmoidectomy (MTR) technique. Methods: 42 patients were evaluated clinically and via AM and P, for postoperative control. The resting, coughing, voluntary contraction, maintained voluntary contraction and perianal stimulation pressures were investigated. The rectosphincteric reflex was tested and the simple and enhanced pressure curves were evaluated. The three-dimensional profilometric outline was produced. Student's t, chi-squared and Fisher's exact tests were used for statistical analysis $(\mathrm{p}<0.05)$. Results: AM showed mean resting pressures of $53.44 \mathrm{mmHg}$ for MDT and $60.67 \mathrm{mmHg}$ for MTR, and mean voluntary contraction pressures of $94.50 \mathrm{mmHg}$ for MDT and 95.47 $\mathrm{mmHg}$ for MTR. There was no statistical difference between the groups. The shapes of the simple and enhanced pressure curves did not present any statistical difference, independent of the surgical technique used. Conclusion: The two surgical techniques were equivalent. MDT caused greater incidence of postoperative constipation that MTR did. AM and P were shown to be excellent tests for postoperative follow-up among these patients.
\end{abstract}

Key words: Hirschsprung's Disease. Megacolon. Surgery. Manometry. Child.

\section{RESUMO}

Objetivo: Avaliar a continência fecal, a manometria anorretal (MAR) e a profilometria (PFM), em pacientes submetidos a tratamento cirúrgico do megacolo congênito pelas técnicas de Duhamel modificado (DM) ou de retossigmoidectomia transanal modificada (RTM). Métodos: 42 pacientes foram clinicamente avaliados e submetidos à MAR e PFM para controle pós-operatório. Foram pesquisadas as pressões no repouso $(\mathrm{PR})$, à tosse $(\mathrm{T})$, à contração voluntária $(\mathrm{CV})$, à contração voluntária mantida $(\mathrm{CVM})$ e à estimulação perianal (EPA). O reflexo reto-esficteriano (RRE) foi testado e as curvas pressóricas simples e potencializada foram avaliadas. Foi elaborado traçado tridimensional de PFM. Utilizamos os testes $t$ de Student, Qui-Quadrado e exato de Fisher para análise estatística $(\mathrm{p}<0,05)$. Resultados: A MAR mostrou médias de $\mathrm{PR}=53,44 \mathrm{mmHg}$ para DM e 60,67 mmHg para RTM; CV média =94,50 mmHg para o grupo DM e 95,47 mmHg para o grupo RTM. Não houve diferença estatística entre os grupos. A forma das CPS e CPP não apresentou diferença estatística, independentemente da técnica cirúrgica utilizada Conclusão: As duas técnicas operatórias foram manometricamente equivalentes. DM determinou maior incidência de constipação pós-operatória que RTM. A MAR e a PFM revelaram-se excelentes exames para acompanhamento destes pacientes após a cirurgia.

Descritores: Doença de Hirschsprung. Megacolo. Cirurgia. Manometria. Criança.

${ }^{1}$ Research performed in the Division of Pediatric Surgery, Department of Surgery, Federal University of São Paulo (UNIFESP), Brazil.

\section{Introduction}

Several procedures have been proposed for definitive surgical treatment of Hirschsprung's disease.

Modified transanal rectosigmoidectomy (MTR) ${ }^{1}$ started to be performed at the UNIFESP in 1999. This consists of an exclusively endoanal pull-through technique with coloanal anastomosis, in accordance with the principles proposed by Swenson. The results from applying this technique have been favorable with regard to subjective assessment using the clinical fecal continence score and evaluation using anorectal manometry. 
It is fundamentally important to provide consistent follow-up for such patients, with the aim of ensuring the advantage of the MTR with total coloanal suture, over the technique proposed by Duhamel ${ }^{2}$ and modified by Martin ${ }^{3}$ that until then had been the procedure of choice in the Coloproctology Unit of the Division of Pediatric Surgery of UNIFESP.

The aim of this study was to evaluate the manometric and profilometric results from two techniques for surgical treatment of Hirschsprung's disease (MDT and MTR), with correlations with the clinical parameters for defecation patterns.

\section{Methods}

The study was approved by the Research Ethics Committee of the Federal University of São Paulo, UNIFESP, São Paulo, SP, Brazil (n. 0938/07). It was performed in the Anorectal Manometry Laboratory, Pediatric Coloproctology Unit, Division of Pediatric Surgery, UNIFESP, Sao Paulo, Brazil.

The sample was composed of 42 patients with Hirschsprung's disease of classical clinical presentation or with a long aganglionic segment who underwent clinical, manometric and profilometric evaluation for postoperative control. Thirty-six were male $(74 \%)$ and six were female $(26 \%)$.

All of the patients' operations were performed by the same staff at Hospital São Paulo. They were separated in two groups, according to the surgical technique used:

\section{Group $1(n=23)$}

Because of clinically, radiologically and manometrically suspected Hirschsprung's disease, these patients underwent colon serosa-muscle biopsy by mean of laparotomy to confirm the diagnosis. During the same procedure, a colostomy was done with two openings in the hepatic flexure of the colon.

Around three to six months after, when the anatomopathological result and the positioning of the transition zone were already known, the definitive procedure was performed. This consisted of colectomy of the aganglionic segment and pull-through of the ganglionic colon using the MDT. The colostomy was closed two to four months after constructing the pull-through ${ }^{2,3,4}$.

\section{Group $2(\mathrm{n}=19)$}

The patients were admitted to hospital three days before the surgical procedure, in order to prepare the colon using a residue-free diet and enemas. On the third day, antibiotic therapy consisting of amikacin and metronidazole at usual doses was started.

By means of an exclusively endoanal route, the patients underwent MTR. The resection level of the aganglionic segment was established with the aid of biopsies to enable anatomopathological identification of the transition cone, by means of frozen section examination. The coloanal anastomosis was constructed in accordance with the principles proposed by Swenson ${ }^{1}$. None of these patients underwent colostomy.

The perianal postoperative stimulation was performed, using the EM-BGE ${ }^{\circledR}$ electrical muscle stimulator, in order to observing whether the patients presented sphincter integrity. The sphincter contraction was shown to be normal in all the patients.
The routine follow-up consisted of return visits every three months over the first year after the operation and return visits every six months thereafter. At these consultations, the patients were measured with regard to their defecation conditions, focusing on constipation and continence.

The patients were individually classified as constipated or non-constipated. They were deemed constipated if the gap between evacuations exceeded three days, independent of whether there were any occurrences of fecal losses or any presence of impacted feces. They were also classified as continent, partially continents or incontinent, in accordance with the Martins criteria $(\text { Chart } 1)^{5}$.

CHART 1 - Martins continence criteria

\begin{tabular}{|l|l|l|l|}
\hline & Continent & $\begin{array}{l}\text { Partially } \\
\text { continent }\end{array}$ & Incontinent \\
\hline $\begin{array}{l}\text { Number of } \\
\text { defecations }\end{array}$ & 1 to $2 \mathrm{x} / \mathrm{d}$ & 3 to $5 \mathrm{x} / \mathrm{d}$ & $\begin{array}{l}\text { More than 5 } \\
\mathrm{x} / \mathrm{d}\end{array}$ \\
\hline $\begin{array}{l}\text { Fecal } \\
\text { consistency }\end{array}$ & Normal & Pasty & $\begin{array}{l}\text { Pasty or } \\
\text { liquid }\end{array}$ \\
\hline $\begin{array}{l}\text { Anal } \\
\text { inspection }\end{array}$ & Normal & $\begin{array}{l}\text { Minimal } \\
\text { prolapse }\end{array}$ & $\begin{array}{l}\text { Large } \\
\text { prolapse or } \\
\text { half-open }\end{array}$ \\
\hline $\begin{array}{l}\text { Digital rectal } \\
\text { examination }\end{array}$ & Normal & $\begin{array}{l}\text { Slight } \\
\text { hypotonia } \\
\text { or } \\
\text { asymmetry }\end{array}$ & $\begin{array}{l}\text { Clear } \\
\text { hypotonia }\end{array}$ \\
\hline
\end{tabular}

The first postoperative manometry was performed 3 months after surgery. Thereafter, it was performed every year, provided that the patient's clinical condition allowed this.

The data obtained for this study correspond to the findings from the patient's most recent anorectal manometry, without sedation, using the perfusion technique proposed by Martins and Esteves ${ }^{6}$.

In the present study, we used the Proctomaster $5.0^{\circledR}$ Dynamed ${ }^{\circledR}$ MPX 816 software. Flexible catheters were used, with a diameter of $4.9 \mathrm{~mm}$, four radial channels (posterior, left lateral, anterior and right lateral) marked out in centimeters, a lumen with insufflations capability and a distal latex balloon with a maximum capacity of $200 \mathrm{ml}$. The distance between the perfusion orifices and the balloon was $3 \mathrm{~cm}$. The data coming from the channels were transmitted through a pneumatic $\mathrm{CO}_{2}$ system, with an infusion pressure of one atmosphere and continuous flow of $0.56 \mathrm{ml} / \mathrm{min}$ of distilled water. The intraluminal contractile activity generated resistance to the water flow perfusing through the orifices. This resistance was quantified as the intraluminal pressure in $\mathrm{mmHg}^{7}$.

The intestinal preparation was performed on the day before the examination, and consisted of an enema of $10 \%$ glycerinated physiological serum solution $(10 \mathrm{ml} / \mathrm{kg})$.

The patients were positioned in right lateral decubitus, with the left knee flexed over the abdomen and the right knee extended, to allow passage of the anorectal manometric catheter, which was introduced as far as $5 \mathrm{~cm}$ from the anal margin. 
After waiting for the sphincter muscle complex to accommodate to the pressure, the catheter was gradually withdrawn. The movement of the catheter along the anal canal was marked out on the computer graphics display, centimeter by centimeter. This procedure enabled identification of the zone of greatest pressure in the anal canal. This zone was then chosen for recording and evaluating the following parameters: resting pressure, sphincter pressure response to coughing, pressure response to voluntary contraction, pressure response to maintained voluntary contraction, pressure response to perianal stimulation, rectosphincteric reflex, simple pressure curve and enhanced pressure curve (Figure 1).

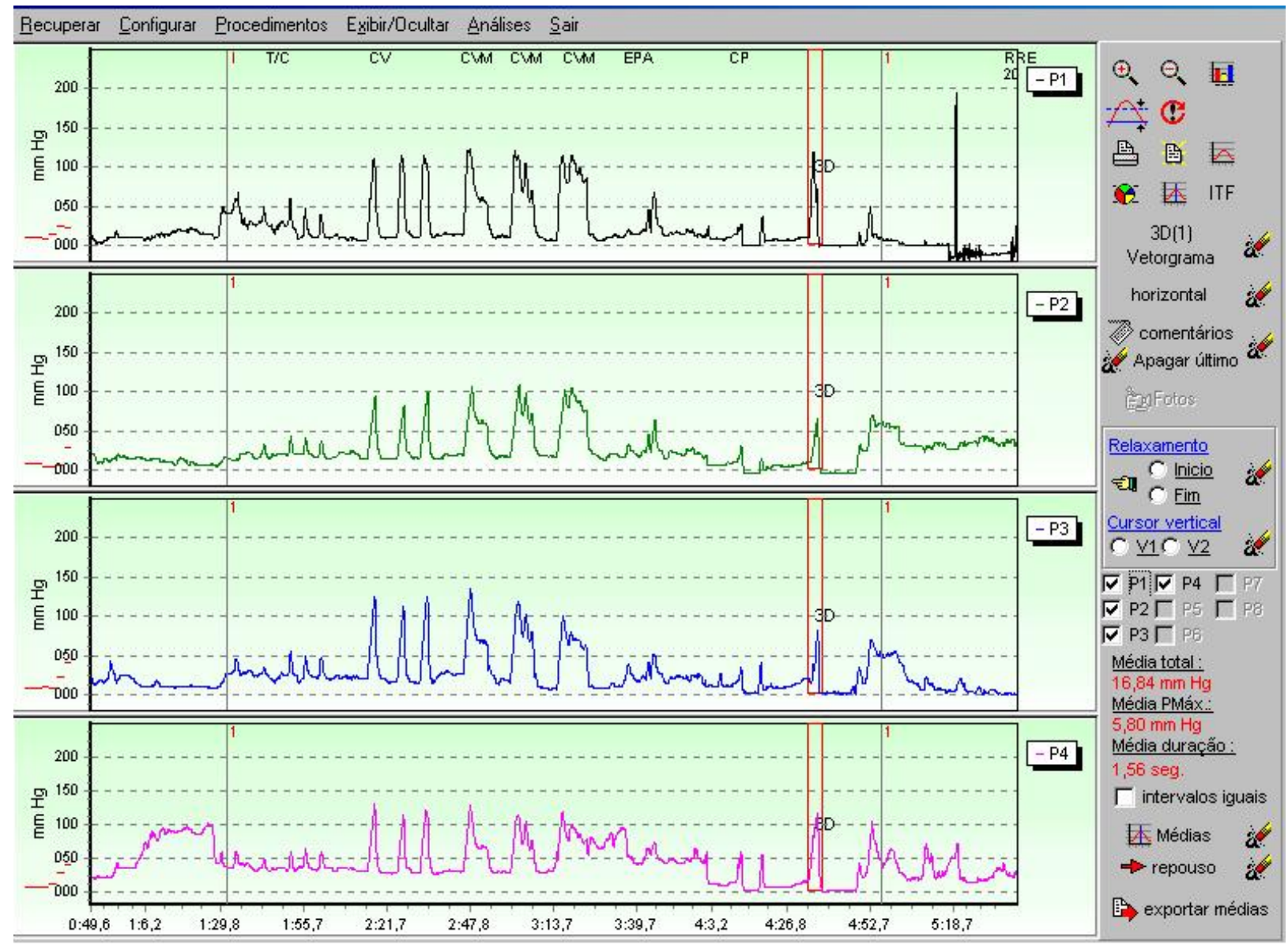

FIGURE 1 - Postoperative anorectal manometry. Patient underwent to MTR

Profilometry (vectorgram) is a technique that allows access to the circumferential symmetry of the anorectal sphincter profile, by means of three-dimensional computerized graphics displaying the pressures resulting from withdrawing the balloon along the anal canal.

The three-dimensional graphical representation of the sphincter apparatus is obtained through the perfusion anorectal manometry technique, both from static moments and from dynamic movements during the examination. From images acquired when constructing the pressure curves for the four perfusion channels, the computer program creates a three-dimensional tracing of the anorectal canal. This makes it possible to analyze indices of total and segmental asymmetry of this duct, the rectal volume $(\mathrm{cm} \mathrm{x} \mathrm{cmHg2)} \mathrm{and} \mathrm{the} \mathrm{pressure} \mathrm{distribution} \mathrm{in} \mathrm{the} \mathrm{anorectal} \mathrm{walls.}$ These are translated by the software as a sequence of colors that correspond to pressures on a previously established scale: green: $<20 \mathrm{mmHg}$; blue: $20-50 \mathrm{mmHg}$; yellow: $50-80 \mathrm{mmHg}$; red: $>80$ mmHg7 (Figure 2). 


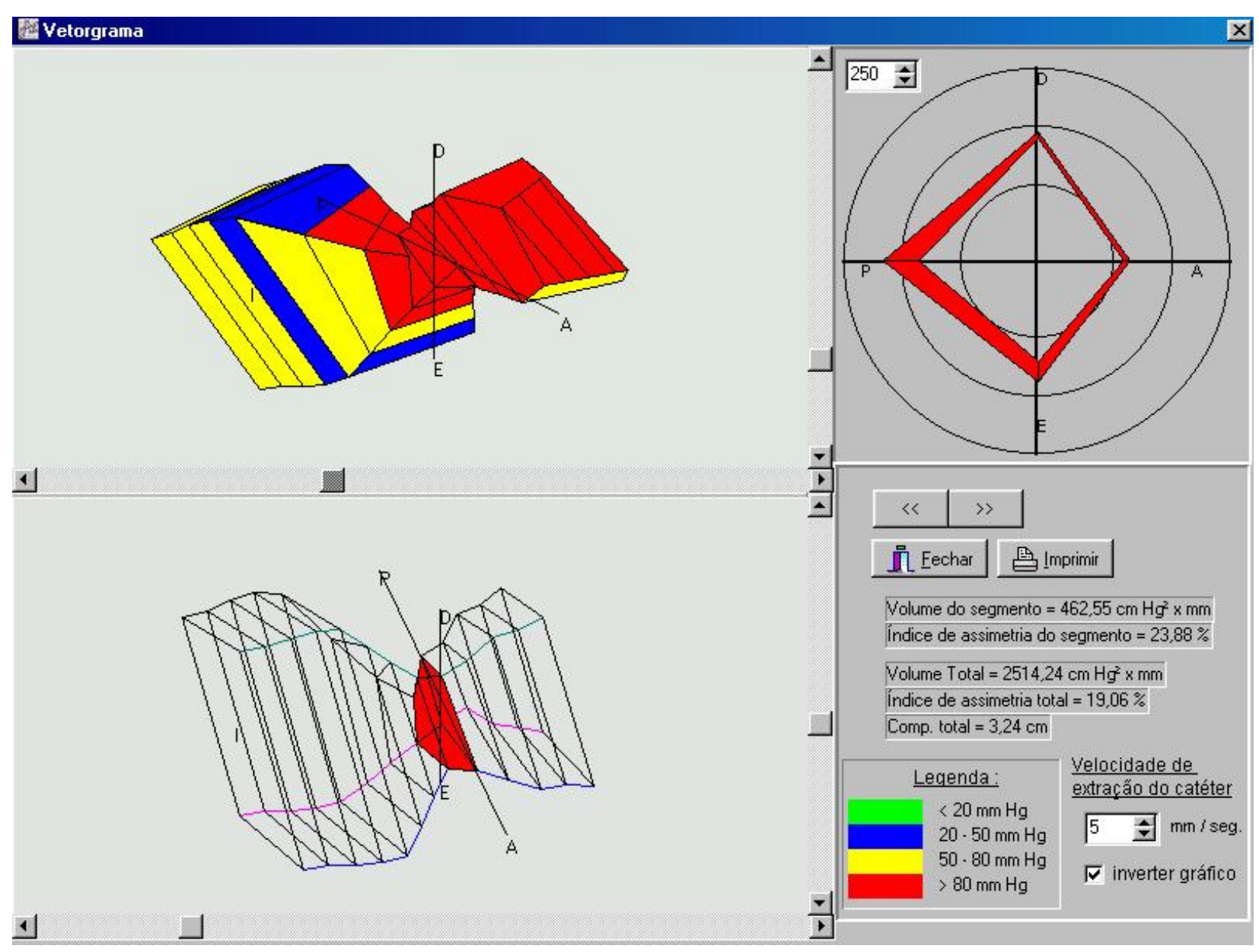

FIGURE 2 - Postoperative profilometry (vectorgram). Patient underwent to MTR

With the aim of comparing the manometric, profilometric and clinical variables between the two surgical techniques, Student's $\mathrm{t}$ test was used, since these were continuous variables. The chi-squared test and, when necessary, Fisher's exact test were used to investigate differences in the distribution of categorized characteristics. The same methodology was used for comparing the variables between the techniques in relation to the continence pattern (continent and partially continent).

The significance level adopted was 5\%.

\section{Results}

Patients underwent to MDT aged 2-15 years, with a mean of 8.7 years. Those who underwent MTR, aged 1-9 years, with a mean of 5 years $(p=0.0003)$.

There was no statistically significant difference between the two techniques with regard to the distribution according to sex.

Recurrence of constipation after surgery occurred in a minority of the patients in the two groups: $34.78 \%$ of the patients who underwent MDT and $5.26 \%$ of those who underwent MTR. The difference between these was statistically significant $(\mathrm{p}=0.0268)$.
No statistically significant differences were observed between the two groups with regard to the manometric variables: resting pressure, sphincter pressure response to coughing, pressure response to voluntary contraction, pressure response to maintained voluntary contraction, pressure response to perianal stimulation, rectosphincteric reflex, simple pressure curve and enhanced pressure curve.

The evaluation of the rectal volume using profilometry did not show any statistical difference between the two techniques. The length of the anal canal among the patients who underwent MDT ranged from 1.13 to $13.72 \mathrm{~cm}$, with a mean of $7.02 \mathrm{~cm}$. This mean was greater than the mean of $4.4 \mathrm{~cm}$ found among the patients who underwent MTR. Among the latter, the measurements ranged from 0.79 to $10.5 \mathrm{~cm}$, and this difference between the MTR and MDT patients was statistically significant.

Most of the patients in the two groups were found to be continent after surgical treatment: $73.7 \%$ of the patients who underwent MTR and 60.9\% who underwent MDT. Nine patients $(39.13 \%)$ who underwent MDT were partially continent, while five $(26.3 \%)$ of those who underwent MTR were partially continent. None of the patients in either of the two groups presented incontinence. 


\section{Discussion}

In this sample, there were 36 male patients (74\%) and six female patients $(26 \%)$, and thus the distribution between the sexes was as expected and as cited in the literature.

The mean age at which the surgical treatment was performed was lower among the patients who underwent the MTR technique than it was for those who underwent MDT, independent of the continence pattern presented by the patients. This difference was also observed by El-Sawaf et al. ${ }^{8}$, in comparing their results from transanal pull-through with those from pull-through via the abdominal route. This can be explained by the advances in knowledge of the disease, which are allowing increasingly early diagnosis and surgical treatment, even during the neonatal period $^{9,10}$.

In the present study, the length of postoperative follow-up for the MTR group is still short, and the mean age among these patients is practically half of the mean age among the MDT group, which does not allow conclusions regarding continence comparisons. We would expect a marked increase in the state of fecal continence, not only because of maturation but also because of the neuroplasticity that becomes established with development.

Fecal continence is defined as the ability to recognize and retain the contents of the rectum and to evacuate them at appropriate times and places ${ }^{11}$. It depends on the compliance of the rectal reservoir, presence of complete sphincter barriers, anorectal sensitivity and preservation of the pelvic reflexes ${ }^{11,12,13,14}$. The upper portion of the anal canal, corresponding to the region of the loop of the puborectal muscle, contributes significantly towards maintaining continence and has great importance in picking up the feeling of rectal fullness through the rectoanal transitional epithelium. Together with the internal anal sphincter, this is the region responsible for discriminating between gases, liquid feces and solid feces.

Fecal continence was observed in $73.7 \%$ of the patients who underwent surgical correction using the MTR technique and in $60.9 \%$ of the patients who underwent the MDT. In our opinion, some of the partially continent patients in the MDT group could be constipated continent individuals who were presenting slight involuntary fecal losses resulting from irritation of the mucosa through the formation of fecalomas. No patients in our sample were diagnosed after the operation as presenting fecal incontinence.

Anorectal manometry is an instrument for measuring anal canal pressures and function. It enables predictions regarding patients' potential for continence. The use of computerized systems not only improves the quality and sensitivity of the tracings but also facilitates the storage of the information, which is important in patient follow-up.

The resting pressure is the predominant factor in maintaining fecal continence ${ }^{12,13,14}$. It is the manometric translation of the internal and external sphincter muscle contraction, such that the internal sphincter is responsible for $85 \%$ of this pressure, while the external sphincter is only responsible for $15 \%{ }^{13}$. In our study, there was no statistically significant difference in resting pressure between the continent and partially continent groups, independent of the technique used. There was no statistically significant difference in resting pressure between the MTR and MDT groups nor when the continent and partially continent patients were compared with each other nor when we compared the resting pressure between the continent and partially continent individuals, independent of the technique used, which corroborates the idea that the fecal losses presented by some patients of this sample were not caused by sphincter lesions.

Constipation and fecal impaction have been reported as complications following Duhamel surgery, with incidence ranging from 7.7 to $31 \%$ of the patients. Slight involuntary fecal losses have been described among 17 to $20 \%$ of the patients ${ }^{15,16,17,18}$. Fecal impaction has been described as the most frequent postoperative complication from this technique ${ }^{17}$, and this may occur secondarily to the development of rectal spurs ${ }^{18}$. The use of longer surgical staplers $(80 \mathrm{~mm})$ and stapling under direct abdominal viewing have been described as preventive factors against the occurrence of spurs.

We observed that complaints of constipation were greater among the patients who underwent the MDT, than among the MTR patients. We believe that the symptoms of constipation, are caused by maintenance of the rectal stump and recurrence of colorectal septa, thus facilitating the formation of fecalomas, as discussed earlier.

However, it needs to be understood that the maintenance of the internal sphincter in the Duhamel technique may also contribute towards the condition of constipation, secondary to achalasia, thus resulting in increased contraction of the internal anal sphincter, which is characteristic of the disease. In some cases, postoperative anorectal myectomy is proposed.

Clamp placement at higher positions, above the internal sphincter, to avoid lesions of this muscle and fecal loss has been described as a technical variation of Duhamel surgery. In our view, this maneuver favors the establishment of determining factor for constipation.

The voluntary contraction pressure is generated primarily by the external anal sphincter muscle and by the levator ani muscle, with a major role played by the puborectal bundle. In general, the normal values found for the maximum voluntary contraction of the anal canal correspond to two to three times the baseline resting pressure. The maximum voluntary contraction achieved has a short duration and is generally maintained for only 50 seconds because of rapid fatigue of the external anal sphincter. These values are found in sporadic situations, with the aim of avoiding undesirable fecal losses, such as in relation to rectal distension, increased intra-abdominal pressure and changes in posture. Physiological decreases in these values are observed with aging, especially after the fifth decade of life.

The external anal sphincter muscle has tonic activity at rest and also during sleep. This activity depends on the completeness of the sacral segments and their peripheral nerve branches. The maximum contraction of the external sphincter can be maintained for approximately one minute. Distension of the rectum or increased pressure within the rectum evokes contraction of this sphincter for around 20 to 30 seconds.

We evaluated this contractile activity by asking the patients to cough and to contract the striated anal musculature. Among the younger children, this examination was sometimes impaired because of difficulty in achieving their cooperation. In such cases, the evaluation was made while they were crying, which is another occasion on which voluntary contractile activity can be found. 
The pressure behavior of the anorectal manometry among the patients in our sample showed mean resting pressures of $53.44 \mathrm{mmHg}$ for MDT and $60.67 \mathrm{mmHg}$ for MTR. In relation to voluntary contractions, a mean of $94.50 \mathrm{mmHg}$ was obtained for the MDT group and $95.47 \mathrm{mmHg}$ for the MTR group. There was no statistically significant difference between the resting and voluntary contraction pressures in the groups. We observed that the mean voluntary contraction pressure was almost twice the resting pressure, which in general is expected when the capacity for continence is investigated. There was no statistically significant difference in the manometric variables, independent of the technique used, whether in the general group, in the continent group or in the partially continent group. Thus, the lack of statistically significant differences relating to the pressure measurements for the internal sphincter, external sphincter or levator ani strengthens the idea that endoanal pull-through, using a coloanal suture technique similar to Swenson's technique, does not cause sphincter lesions.

As described by Vital Junior et al. ${ }^{12}$, the existence of alterations on the pressure curves is suggestive of lesions in the anal canal. In our sample, there were no statistically significant differences in the enhanced pressure curves when the two surgical techniques were compared. Likewise, there was no statistically significant difference when the pressure measurements on the curves for the continent patients were compared within each technique, or when pressure measurements on the curves for the partially continent patients were compared.

Through the use of continuous flow manometry, it became possible to construct the pressure profile of the anorectal canal three-dimensionally, i.e. to determine its profilometry. The analysis of these data can be transformed into a mathematical expression of sphincter symmetry, measured under resting pressure conditions or during maximum voluntary contraction ${ }^{12,14}$.

We believe that this stage of computerized manometric examinations is one of the major innovatory contributions towards postoperative care for patients undergoing pull-through operations on the colon. It provides reliable information relating to the three-dimensional topography of the anorectal canal (length and volume measurements on the anal canal) and also with regard to the distribution of the pressures involved in the process of anorectal fecal continence, thereby greatly assisting in the clinical management of these patients.

We observed that there were no lesions of the sphincter muscle complex, as shown by the manometry and profilometry on the MTR cases among our sample. This was similar to the findings of Till et al. ${ }^{17}$.

The anal canal is the terminal portion of the intestine. It starts at the anorectal junction, has a length of three to four centimeters and ends at the anal margin. Its length is an important factor in relation to anorectal continence. The functional length of the anal canal may not be equal to the anatomical length. The functional anal canal may be significantly longer in males than in females because of the greater muscle mass in males.

It was demonstrated through profilometric tracings that there was resistance in the anal canal when it had a length of greater than or equal to $2.5 \mathrm{~cm}$. They reported that short anal canals $(<1.2$ $\mathrm{cm})$ generally offered little resistance and had a high sensitivity threshold. Both of these characteristics were associated with fecal incontinence ${ }^{12}$. This mechanical resistance was related to radial pressure in the anal canal and to the length of the anal canal.
Among the 42 patients in this sample, the length of the anal canal ranged from 0.79 to $13.72 \mathrm{~cm}$, with a mean of $7.65 \mathrm{~cm}$. The mean length of the anal canal among the continent patients was $4.79 \mathrm{~cm}$, while it was $7.93 \mathrm{~cm}$ among the partially continent group. This was a statistically significant difference.

For the MTR group, the mean length of the anal canal was $4.40 \mathrm{~cm}$, while in the MDT group it was $7.02 \mathrm{~cm}$. This difference was also statistically significant.

No statistically significant difference was observed in the measurements of anal canal length between the continent and partially continent groups, among the patients who underwent surgical correction using the MTR technique. Among the patients in the MDT group, there was greater anal length among the partially continent individuals $(9.04 \mathrm{~cm})$ than among the continent individuals $(5.72 \mathrm{~cm})$.

When we analyzed the continent patients, there was no statistically significant difference in the anal canal measurements, independent of the technique. The same occurred when we evaluated the partially continent patients.

In our view, the presence of a longer anal canal may be associated with a large rectal stump caused by colorectal spurs. This results in slight involuntary fecal losses that may be confounded with the findings from partially continent individuals.

\section{Conclusions}

The two operative techniques were equivalent from the manometric and profilometric point of view. The MTR technique seems to have been shown to be an excellent therapeutic choice for definitive surgical treatment on patients with congenital megacolon, thereby enabling an early surgical approach, even at the neonatal stage. It does away with the need to construct colostomies and results in a lower incidence of postoperative constipation. Nevertheless, a larger sample and longer postoperative follow-up will still be needed in order to obtain definitive results.

MDT on this sample caused greater incidence of postoperative constipation than MTR did.

Manometry and profilometry were shown to be excellent tests for postoperative follow-up on patients undergoing surgical treatment for congenital megacolon.

\section{References}

1. Peterlini FL, Martins JL. Modified transanal rectosigmoidectomy for Hirschsprung's disease: clinical and manometric results in the initial 20 cases. J Pediatr Surg. 2003;38(7):1048-50.

2. Duhamel B. Retrorectal and transanal pull-through procedure for the treatment of Hirschsprung's disease. Dis Colon Rectum.1964;7:455-8.

3. Martin L, Caudill D. A method for elimination of the blind rectal pouch in the Duhamel operation for Hirschsprung's disease. Surgery. 1967;62:951-3. 4. Peterlini FL, Martins JL, Cury EK. Tratamento cirúrgico do megacolo congênito pela técnica de Duhamel, utilizando-se pinças ou grampeador cirúrgico. Folha Méd. 2001;14:85-7.

5. Martins JL, Pinus J. Anorectal manometry in child assessment of 1153 examinations performed from 1987 to 1995 . Rev Hosp São Paulo Esc Paul Med. 1995;6:80-2.

6. Martins JL, Esteves E. Evaluación de la motilidad anorrectal por manometria computarizada en la infancia. Rev Cir Infant. 1996;6(4):177-80. 
7. Sun WM, Rao SSC. Manometric assessment of anorectal function Gastroenterol Clin North Am. 2001;30:15-32.

8. El-Sawaf MI, Drongowski RA, Chamberlain JN, Coran AG, Teitelbaum $\mathrm{DH}$. Are the long-term results of the transanal pull-through equal to those of the transabdominal pull-through? A comparison of the 2 approaches for Hirschsprung's disease. J Pediatr Surg. 2007;42:41-7.

9. Saad LHC, Coy CSR, Fagundes JJ. Quantificação da função esfincteriana pela medida da capacidade de sustentação da pressão de contração voluntária do canal anal. Arq Gastroenterol. 2002;39:233-9.

10. Jorge JMN, Wexner SD. Anorectal manometry: techniques and clinical. South Med J. 1993;86:924-31.

11. Zaslavsky C, Loening-Baucke V. Anorectal Manometric evaluation of children and adolescents postsurgery for Hirschsprung's disease. J Pediatr Surg. 2003;38:191-5.

12. Vital Junior PF, Martins JL, Peterlini FL. Posterior sagittal anorectoplasty in anorectal anomalies: clinical, manometric and profilometric evaluation. Sao Paulo Med J. 2007;125(3):163-9.
13. Perry RE, Blatchford GJ, Christensen MA. Manometric diagnosis of anal sphincter injuries. Am J Surg. 1990;159:112-7.

14. Teitelbaum DH, Cilley RE, Sherman NJ. A decade of experience with the primary pull-through for Hirschsprung's disease in the newborn period: a multicenter analysis of outcomes. Ann Surg. 2000;232:372-80. 15. Chiengkriwate P, Patrapinyokul S, Sangkhathat VC. Primary pull-through with modified Duhamel Technique: one institution's experience. J Pediatr Surg. 2007;42:1075-80.

16. Schuster T, Joppich I, Schneider K. A computerized vector manometry study of so-called ectopic anus. Pediatr Surg Int. 2000;16:8-14.

17. Till H, Heinrich M, Schuster T, Scweinitz D. Is the anorectal sphincter damaged during a transanal endorectal pull-through (TERPT) for Hirschsprung's disease? A 3-dimensional, vector manometric investigation. Eur J Pediatr Surg. 2006;16(3):188-91.

18. Nasr A, Langer JC. Evolution of the technique in the transanal pull-through for Hirschsprung's disease. J Pediatr Surg. 2007;42(1):36-9.

\section{Correspondence:}

José Luiz Martins

Rua dos Otonis, 131

04025-000 Sao Paulo - SP Brazil

Tel/Fax: (55 11)5575-4761

jlmartins1@terra.com.br

Conflict of interest: none Financial source: none

Received: March 10, 2009

Review: May 12, 2009

Accepted: June 15, 2009

\section{How to cite this article}

Martins ELS, Peterlini FL, Fagundes DJ, Martins JL. Clinical, manometric and profilometric evaluation after surgery for Hirschsprung's disease. Comparison between the modified Duhamel and the transanal rectosigmoidectomy techniques. Acta Cir Bras. [serial on the Internet] 2009 Sept-Oct;24(5). Available from URL: http://www.scielo.br/acb

*Color figures available from www.scielo.br/acb 